\title{
LCA Design Considerations for Cyclically Loaded Piles in Railway Infrastructure
}

\author{
Anders Beijer Lundberg \\ ELU Konsult AB, Sweden \\ E-mail: anders.beijer@elu.se
}

\begin{abstract}
Future development of high-speed railways in Sweden will likely contain a large amount of piled structures, both bridges and piled embankments. Railway tracks used in high-speed railways are highly sensitive to settlements, in comparison to standard railway systems. The possible long-term settlement of the piles is therefore of large interest for the lifeCycle Analysis (LCA) of the railway system, since frequent repair of the track increases the Life Cycle Cost (LCC) of the system. This issue has not previously been the main concern in pile design, and therefore requires special attention as an internal part of the railway support system. The design considerations related to the cyclic axial loading of piles are here analyzed in brief, and typical soil conditions are discussed to illuminate possible problems of practical design for these types of piles and how it can be addressed in practical design. The concept of LCA and LCC for the long-term structural response of cyclically loaded piles is also considered.
\end{abstract}

Keywords: piles, LCA, LCC, long-term settlements, cyclic load, railway maintenance.

Conference topic: Geotechnical art and historical experience.

\section{Introduction}

The development of high-speed railways is currently considered in Sweden. Such railways involve the largescale planning and design of a new railway system. This design and construction involves many challenges that have previously not been considered in design, such as the need for very limited settlements over the life-time of the railway structure. Herein such design consideration related to cyclic axial loading of piles are elaborated upon and discussed.

\section{Methodology}

Experiences and challenges of pile design for highspeed railway is initially presented. Subsequently a more detailed presentation of cyclic axial loading of piles and the possible design states is given. This will be centred on the importance of the serviceability limit state for the overall design of the high-speed railway tracks. The use of Life Cycle Analysis and Life Cycle Cost analysis for piled structures is then discussed. A suitable methodology for design of cyclically loaded piles is elaborated.

\section{Design of piles}

Piles are designed according to the Eurocode 7 in Sweden, (Eurocode 7 1997). Piles in high-speed railway structures will generally be used in bridge structures or in piled embankments. A typical piled embankment is shown in Figure 1. The most common pile types in Sweden are driven reinforced precast concrete piles and driven tubular steel piles.

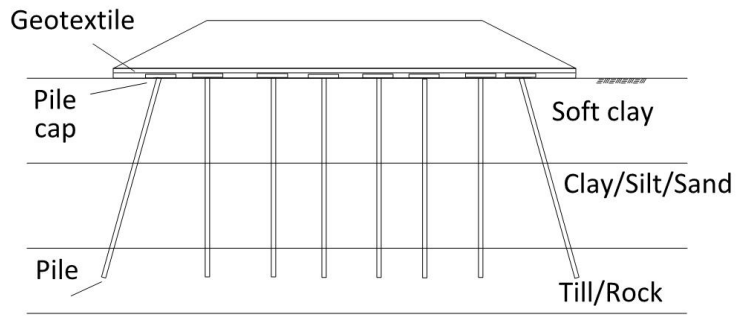

Fig. 1. Idealized cross-section of a piled embankment

\section{Soil conditions}

The soil strata in Sweden is characterized by the geological conditions resulting from the last ice age, in which very soft clay was deposited on till and rock, as shown in Figure 1. In between the clay and the till or the rock, other types of sedimentary soils are found, such as silt or grains with larger diameter. Since the compact rock or till is frequently found at a relatively shallow depth, piles are typically designed as end-bearing columns in which control of the geotechnical bearing capacity is carried out through high-strain dynamic pile load testing, (Grävare et al. 1980). The structural capacity of the pile is subsequently assessed through an analysis of the buckling and pile material capacity, (Wennerstrand, Fredriksson 1988). The possible settlement in serviceability limit state of such piles is normally not assessed in practical design, since it is assumed that the settlement levels are relatively low and therefore not damaging for normal structures. 


\section{Design states}

Possible design states include Ultimate Limit State (ULS), Serviceability Limit State (SLS) and Accidental Limit State (ALS), shown in Figure 2. The pile design considers both the geotechnical and structural bearing capacity. The experience of the design of railway tracks and bridges for both the geotechnical and structural bearing capacity of end-bearing piles implies that design methods used for the ULS and ALS are robust, and should not present any challenge in the design of high-speed railways. However, the knowledge about possible pile settlements during longterm cyclic loading is relatively limited: Swedish experience of axially loaded piles shows that the settlement of structures supported by mainly end-bearing piles is not a major issue in design. However, the high-speed railways will have much more strict settlement limitations, with a service life of 120 years for the piles, and a settlement criterion in SLS of less than $20 \mathrm{~mm}$ (Trafikverket 2016). Small deformations during cyclic loading could therefore have a large effect on the railway structure.

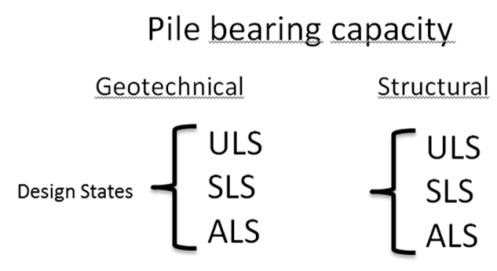

Fig. 2. Possible design states for piles

\section{Axial cyclic loading of piles}

The cyclic response of axially loaded piles has been studied in the field and laboratory, and a theoretical basis to assess such piles has been established (Baumbach 2012; Chen et al. 2013; Jardine, Standing 2000). The distribution between the static and cyclic loads is normally expressed through the static load ratio $(S L R)$ and the cyclic load ratio $(C L R)$ according to Eqs (1) and (2). The static and cyclic loads are defined according to Figure 3.

$$
\begin{aligned}
& S L R=\frac{P_{\text {Static }}}{P_{\text {Capacity }}} ; \\
& \text { CLR }=\frac{P_{\text {Cyclic }}}{P_{\text {Capacity }}},
\end{aligned}
$$

where: $P_{\text {Static }}$ is the static load, $P_{\text {Cyclic }}$ is the cyclic load, and $P_{\text {Capacity }}$ is the total static capacity. In the case of purely static load, the static load ratio is 1 . In practical design, a safety factor will be used, and the static design capacity, $P_{\text {Capacity,design }}$ is defined relative to the factor of safety $\gamma_{S F}$ :

$$
P_{\text {Capacity, design }}=\frac{P_{\text {Capacity }}}{\gamma_{S F}},
$$

where the factor of safety is adapted from Eurocode 7, (Eurocode 7 1997).

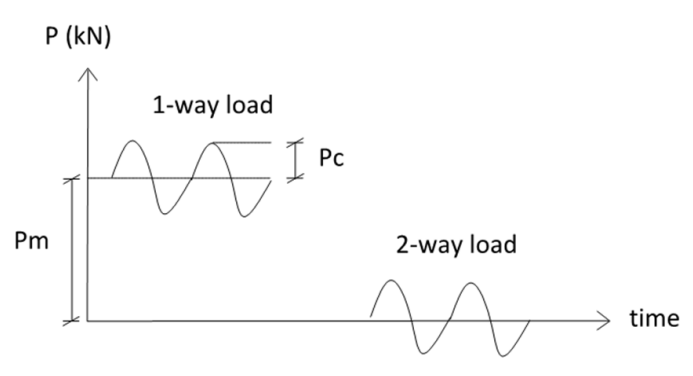

Fig. 3. Definition of cyclic load on piles

Cyclically loaded piles typically exhibit a lower bearing capacity compared to statically loaded piles due to the reduction of the shaft capacity of the piles with an increasing amount of load cycles. The bearing capacity of cyclically loaded piles depends on the static and cyclic load ratios, and whether the piles are loaded in 1-way or 2 way cycles, according to Figure 3, (Jardine, Standing 2000). Socalled cyclic stability diagrams have been constructed after the result of field tests, and follow the outline in Figure 4. Depending on the static and cyclic load ratio, the piles exhibit an unstable, meta-stable or stable response. In the unstable response the pile loses its bearing capacity after a few load cycles, in the meta-stable zone the pile can resist a larger amount of load cycles and may therefore be acceptable in design, and in the stable zone the pile provides a stable response with little change in stiffness or deformation level through the lifetime of the pile.

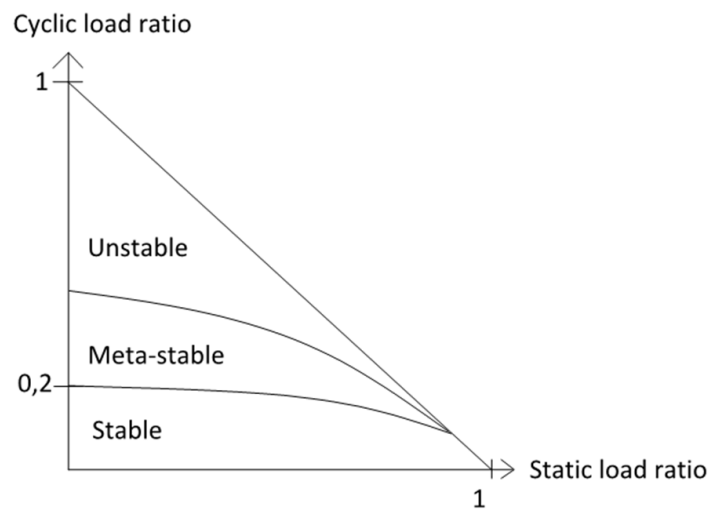

Fig. 4. Cyclic stability diagram

The cyclic stability diagram assesses the ULS of the pile. Field and laboratory measurements however show that piles loaded at low cyclic load levels (In the stable zone in Figure 4) may exhibit relatively large accumulated settlements, that could be of interest in the design structures sensitive to settlements, such as high-speed railway lines (Baumbach 2012). The development of settlements may follow a logarithmic curve relative to the amount of load cycles, as shown in Figure 5 for three different load series that occur through the life-time of a structure (Chen et al. 2013). 


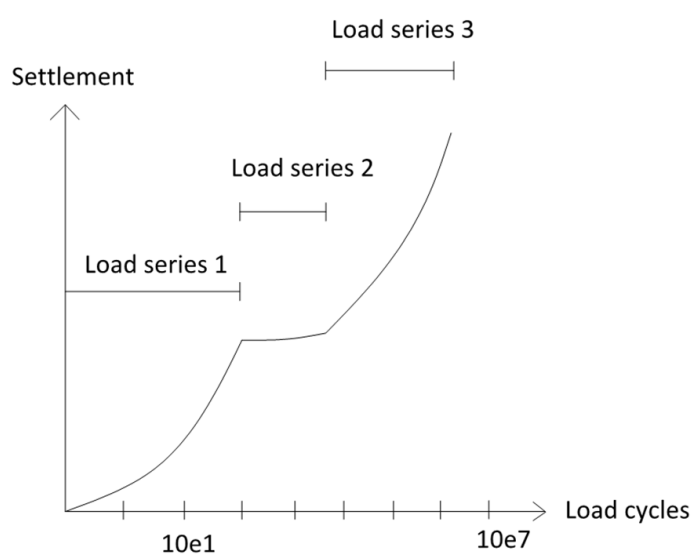

Fig. 5. Settlement versus load cycles for different load series

\section{Cyclically loaded piles in Swedish soil conditions}

Idealized soil conditions in Sweden which are suitable for end-bearing piling are shown in Figure 1. The top soil layer in such soil strata frequently consists of a shallow layer of dry crust, followed with a soft clay layer (often between 1-20 m depth), followed by a silt/sand layer on top a compact till and hard rock. In the case of a railway track passing through a hill and valley landscape, the soil strata is prone to very variable, with changing depth to rock as well as a changing size of the silt/sand/till layer. The pile response will consequently be very stiff at locations where it is possible to penetrate into the compact till or rock. At other locations, however, the tip of the end-bearing pile will more likely be located 1-3 m into the silt/sand/till layer. The endbearing resistance in such cases will be derived from both the shaft and the tip, and cyclic loading is prone to cause some settlements of the soil. Field measurements show that the majority of the bearing capacity of a pile located in a sandy soil originates from the shaft at small displacements, and that the momentary displacement is around $1 \mathrm{~mm} / 100 \mathrm{kN}$ for such a pile (Rankka 1991). Some displacement will probably be mobilized in every load cycle, while a certain amount of the displacement results from the permanent load. Some pile settlements should therefore be expected, depending on the depth of the softer silt/sand/till layers. Another factor that could also result in pile settlement is the difference between the pile design load and the actual load. The load conditions within the piled embankment are somewhat uncertain, and depend on the arching in the soil. This could result in a higher proportion of the load going into the piles centred beneath the track and less into the geotextile, (Low et al. 1994). This extra pile load may not ben an issue in ULS, but could possibly lead to more settlement.

\section{LCA and LCC}

The design of large-scale long-term infrastructure projects is normally accompanied by a Life Cycle Analysis (LCA). In such a study the different design and con- struction techniques under considerations are described, including the need for repair and maintenance cost during the life-time of the structure, (Frangopol et al. 1997). A Life-Cycle Cost (LCC) analysis, in which the cost of construction and maintenance is taken into account, is then carried out to find a design that minimizes the total cost during the life-time of the project (Wen, Kang 2001). The uncertainty in the different stages of the design is also taken into account.

Such an analysis is frequently conducted for structures such as bridges, but more seldom for soil structures (Wen, Kang 2001). The method is however often used in railway track planning, (Patra et al. 2009). Recently more detailed methods to conduct such analysis for soil structures have appeared, in the case of specialized retaining structures as well as for roads (Hayashi, Nishimoto 2008; Requin, Lasne 2012). This is a promising development for detailed analysis of construction costs in field that is dominated by a large uncertainty about the ground conditions (Whitman 2000).

However, the different design states (ULS, ALS, SLS) in Eurocode 7 behave different during the lifetime of the structure (Eurocode 7). The stability of a structure in ULS could increase as consolidation of the soil proceeds. The same mechanism could lead to a lower safety in SLS when settlements appear. A detailed long-term design strategy in which the different design states and the parameters that influence them change during the life-time of the structure is needed.

\section{Life-cycle analysis of piles for high-speed railways}

The life-cycle cost of a structure is heavily influenced by the original design, resulting in a balance between the construction and maintenance cost, (Hayashi, Nishimoto 2008). High-speed railways are built on bridges or embankments, with a ballasted system or a ballast-free system, such as a slabtrack (Esveld 2003). The purpose of the slabtrack method is to reduce the LCC of the structure by building a more robust system, albeit with a higher initial cost.

The slabtrack system is however sensitive to settlements of the substructure, which should be assured through a robust design. The substructure in soft soils may consist of a piled embankment, or some type of ground improvement, e.g. deep-mixed columns.

Design of a piled embankment contains specification of the distance between the piles and the bearing capacity in each design state, according to Figure 2. In practical design, the structural capacity is calculated based on the soil conditions, (Wennerstrand, Fredriksson 1988), and sufficient geotechnical capacity for a certain amount of the piles is measured in high-strain dynamic pile load tests (Grävare et al. 1980).

The design method has a proved track record for the ULS and ALS design states, as shown in Figure 2. But the experience of the SLS design state is limited, since settlements are typically relatively small. For high-speed railway, these small settlements will be of large interest and should be estimated in detail. 


\section{Proposed methodology for assessment of settlements in SLS from axial cyclic pile loading}

Most previous research on axial cyclic pile loading has focused on the capacity of the pile in ULS, e.g. (Jardine, Standing 2000). More recently the long-term settlement process has been studied in different soils, and a logarithmic load-cycle versus settlement curve has been proposed based on experimental results (Baumbach 2012; Chen et al. 2013). The practical design of axially loaded piles in SLS however requires a methodology that is both relatively straight-forward as well as suitable for the proposed construction technique, in this case driving of reinforced concrete piles.

The design of a piled embankment in Sweden is frequently based on a relatively sparse site investigation with little information about the soil parameters. The final capacity of the piles is measured by high-strain dynamic pile tests after the installation of the piles, (Grävare et al. 1980). The reduction of pile capacity resulting from the risk of long-term settlements needs to be assessed based on the local soil data, but also through a suitable calculation model. Table 1 illustrates the phases of a proposed design method.

Table 1. Phases in practical assessment of the risk of long-term settlements for axially loaded piles

\begin{tabular}{l|l}
\hline \multicolumn{1}{c|}{ Phase } & \multicolumn{1}{c}{ Action } \\
\hline $\begin{array}{l}\text { Assessment of the soil } \\
\text { strata for a specified } \\
\text { cross-section }\end{array}$ & $\begin{array}{l}\text { Quantifying the risk of deep } \\
\text { layers of silt/sand/soft till }\end{array}$ \\
\hline $\begin{array}{l}\text { Specifying the risk of } \\
\text { long-term settlements } \\
\text { for the soil strata }\end{array}$ & $\begin{array}{l}\text { The soil strata is compared to } \\
\text { results from a parameter study of } \\
\text { different soil conditions, and a } \\
\text { likely response is estimated }\end{array}$ \\
\hline $\begin{array}{l}\text { Design of the pile } \\
\text { bearing capacity in }\end{array}$ & $\begin{array}{l}\text { A reduction factor based on the } \\
\text { parameter study is used to assure } \\
\text { that the long-term settlements are } \\
\text { limited }\end{array}$ \\
\hline Construction of piles & $\begin{array}{l}\text { The pile driving data is analyzed } \\
\text { with wave-equation programs to } \\
\text { assess the soil strata for all the } \\
\text { piles in the group }\end{array}$ \\
\hline Pile testing & $\begin{array}{l}\text { High-strain dynamic pile load } \\
\text { tests are carried out to assess the } \\
\text { capacity in ULS }\end{array}$ \\
\hline $\begin{array}{l}\text { Long-term settlement } \\
\text { monitoring }\end{array}$ & $\begin{array}{l}\text { The settlement of the railway } \\
\text { track is monitored through the } \\
\text { life-cycle of the structure }\end{array}$ \\
\hline
\end{tabular}

\section{Conclusions}

A brief analysis of cyclically loaded piles shows that practical design will probably be concerned with the serviceability limit state (SLS), due to the large experience of piles for relatively similar types of loads in the ULS and ALS design states. A proposed design methodology has been presented. A more detailed numerical parameter study on cyclic pile loading in suitable soils is needed in order to assess the risk of long-term settlements based on information of the specific soil strata.

\section{Disclosure statement}

The author of the article does not have any competing financial, professional, or personal interests from other parties.

\section{References}

Baumbach, J. 2012. Ergebnisse axial-zyklischer Belastungsversuche unter Schwell- und Wechsellasten an Mikropfählen in Ton, BAW mittteilungen 95: 107-124.

Chen, R. P.; Ren, Y.; Zhu, B.; Chen, Y. M. 2013. Deformation behaviour of a single pile in silt under long-term axial loading, ICSMFE2013, 1-3 September 2013, Paris, France.

Esveld, C. 2003. Recent developments in slab track, European Railway Review 9(2): 81-85.

Eurocode 7. Geotechnical design: part 1 - general rules. Brussels, 1997.

Frangopol, D. M.; Lin, K. Y.; Estes, A. C. 1997. Life-cycle cost design of deteriorating structures, Journal of Structural Engineering 123: 10: 1390-1401. http://dx.doi. org/10.1061/(ASCE)0733-9445(1997)123:10(1390)

Grävare, C. J.; Goble, G. G.; Rausche, F.; Likins, G. E. 1980. Pile driving construction control by the Case method, Ground Engineering13(2): 20-25.

Hayashi, H.; Nishimoto, S. 2008. A case study of the longterm settlement and life cycle cost of a road on peaty ground, in Proceedings of the International Conference Advances in Transportation Geotechnics, 25-27 August 2008, Nottingham, UK, 397-400.

Jardine, R. J.; Standing, J. R. 2000. Pile load testing performed for HSE cyclic loading study at Dunkirk, France, Vol. 1. HSE study, OTO.

Low, B. K.; Tang, S. K.; Choa, V. 1994. Arching in piled embankments, Journal of Geotechnical Engineering 120(11): 1917-1938. http://dx.doi.org/10.1061/(ASCE) 0733-9410(1994)120:11(1917)

Patra, A. P.; Söderholm, P.; Kumar, U. 2009. Uncertainty estimation in railway track life-cycle cost: a case study from Swedish National Rail Administration, Journal of Rail and Rapid Transit 223(3): 285-293. http://dx.doi.org/10.1243/09544097JRRT235

Rankka, K. 1991. Friktionspålars bärförmåga och last/förskjutningssamband, IVA Pålkommission.

Requin, A.; Lasne, M. 2012. Life cycle analysis and special geotechnical works: development of an operational calculation tool, in A. Ventura, C. de la Roche (Eds.). International Sympositium on Life Cycle Assessment and Construction - Civil Engineering and Buildings. RILEM Publications SARL, 179-186.

Trafikverket. 2016. Technical system standard for high-speed tracks. TDOK 2014:0159, workpiece, 2016.

Wen, Y. K.; Kang, Y. J. 2001. Minimum building life-cycle cost design criteria. I: methodology, Journal of Structural Engineering 127(3): 330-337.

http://dx.doi.org/10.1061/(ASCE)0733-9445(2001)127:3(330)

Wennerstrand, J.; Fredriksson, A. 1988. Capacity of slender steel piles, in $1^{\text {st }}$ Geotechnical Seminar on Deep Foundations and Auger Piles, 12-14 November, Gent, Belgium.

Whitman, R. V. 2000. Organizing and evaluating uncertainty in geotechnical engineering, Journal of Geotechnical and Geoenvironmental Engineering 126: 583-593.

http://dx.doi.org/10.1061/(ASCE)1090-0241(2000)126:7(583) 